\title{
CHARACTERIZATION AND IDENTIFICATION OF POLYACRYLONITRILE FIBRES AND THEIR MODIFICATIONS AND MODACRYLIC FIBRES BY INFRARED SPECTROMETRIC METHOD
}

Polyacrylonitrile fibres, often shortly called polyacrylic fibres, are known under several hundred trade names. The world output of synthetic polyacrylic fibres has attained the third place after polyester and polyamide fibres.

According to the recommendation 20761973 of the International Standardization Organization (ISO), polyacrylic fibres are synthetic fibres formed from such high polymers which have been linearly polymerized from at least $85 \%$ of vinyl cyanide/acrylonitrile [']. Modacrylic fibres are synthetic fibres formed by linear polymerization from less than 85 wt. \%, but more than 50 wt. \% of acrylonitrile. In the ISO's recommendation 2076/DAM 2 the lower linitit is terminologically incorrectly fixed, it being at least 35 wt. \% of acrylonitrile. Acrylonitrile is subjected to emulsion (suspension) or solvent polymerization in the redox system in aqueous ammonium peroxydisulfate solution $(1: 10)$ in the presence of sodium hydrogen sulfate or sodium thiosulfate as catalysts with an average molecular mass of 60000 to 100000 (the chain containing 1200 or 2000 basic molecules, respectively) [2,3].

The pure polyacrylic fibres thus obtained are used as technical fibres and together with viscose fibres also in manufacturing carbon fibres. In order to gain better textile-technological properties and fibre dyeing, pure acrylonitrile is not polymerized alone, but appropriate unsaturated monomers such as vifiyl acetate, vinyl pyridine, methyl methacrylate and acrylamide are added, which at polymerization break the polyacrylonitrile structure, thus promoting the absorption of dyes into the polymer, or alkaline groups are added which permit the use of acid dyes by dyeing $\left[{ }^{4}\right]$. -07 As the amounts of additives in the polymers modified this way are lower than $15 \%$, then according to the definition such polymer fibres belong to polyacrylonitrile fibres. Most of them containd $89+95 \%$ of polymerized acrylonitrife and $5-11 \%$ of some comonomer, i e. g., 2 an acetate-, sulfo- or sulfonate group [5] or some other groups. The wide use of polyacrylic fibres for manufacturing textile fabrics and carpets suggested the need for improving their flameproof properties. Most of the acrylic fibres used nowadays are made more flameproof by introducing high amounts of halogen-containing components into the polymer. Such fibres are called modacrylic or also multipolymerizate fibres. As comonomers, vinyl chloride or vinylidene chloride are used, $35-50 \%$ of them being polymerized into a polymer.

79 In this work, two modacrylic q fibres (Dynel and Verel 17) were subjected to investigation. Their elemental analysis is given in Table 1 , and absorption bands of infrared spectra in Table 2. As comonomers, vatious chemical compounds are used,' such las inyl pyrrolidone, alkyl 
Elemental analysis of some investigated polyacrylonitrile fibres, $\%$

\begin{tabular}{|c|c|c|c|c|c|}
\hline \multicolumn{2}{|c|}{ Fibres } & \multirow{2}{*}{ C } & \multirow{2}{*}{$\mathrm{H}$} & \multirow{2}{*}{$\mathrm{N}$} & \multirow{2}{*}{$\mathrm{C}+\mathrm{H}+\mathrm{N}$} \\
\hline Trade name & Proveniance & & & & \\
\hline \multicolumn{6}{|c|}{ Polyacrylic } \\
\hline $\begin{array}{l}\text { Acribel } \\
\text { Acrilan } \\
\text { Cashmilon } \\
\text { Creslan } \\
\text { Crylor } \\
\text { Dolan } \\
\text { Dralon } \\
\text { Exlan L } \\
\text { Exlan S } \\
\text { Nitron } \\
\text { Prelana } \\
\text { Tacryl A } \\
\text { Vonnel } \\
\text { Zefran }\end{array}$ & $\begin{array}{l}\text { Belgium } \\
\text { USA } \\
\text { Japan } \\
\text { USA } \\
\text { France } \\
\text { GFR } \\
\text { GFR } \\
\text { Japan } \\
\text { Japan } \\
\text { USSR } \\
\text { GDR } \\
\text { Sweden } \\
\text { Japan } \\
\text { USA }\end{array}$ & $\begin{array}{l}66.90 \\
65.61 \\
66.09 \\
67.00 \\
67.19 \\
66.95 \\
65.90 \\
66.09 \\
67.61 \\
67.61 \\
67.06 \\
66.44 \\
66.48 \\
67.14\end{array}$ & $\begin{array}{l}5.93 \\
5.48 \\
5.83 \\
5.73 \\
5.81 \\
6.00 \\
5.84 \\
5.74 \\
5.70 \\
5.69 \\
5.77 \\
5.78 \\
5.85 \\
5.83 \\
\end{array}$ & $\begin{array}{l}24.50 \\
23.41 \\
24.71 \\
25.44 \\
24.86 \\
24.58 \\
24.37 \\
23.71 \\
23.62 \\
25.36 \\
25.89 \\
24.45 \\
23.61 \\
25.01\end{array}$ & $\begin{array}{l}97.33 \\
94.50 \\
96.63 \\
98.17 \\
97.86 \\
97.53 \\
96.11 \\
95.54 \\
96.93 \\
98.66 \\
98.72 \\
96.67 \\
95.94 \\
97.98\end{array}$ \\
\hline \multicolumn{6}{|c|}{ Modacrylic } \\
\hline $\begin{array}{l}\text { Dynel } \\
\text { Verel } 17\end{array}$ & $\begin{array}{l}\text { USA } \\
\text { USA }\end{array}$ & $\begin{array}{l}53.26 \\
49.98\end{array}$ & $\begin{array}{l}5.71 \\
5.02\end{array}$ & $\begin{array}{l}10.65 \\
13.01\end{array}$ & $\begin{array}{l}69.58 \\
68.01\end{array}$ \\
\hline
\end{tabular}

vinyl sulfone, styrene sulfonic acid, vinyl phosphonic acid, polymerizing dicarboxylic acid, etc. [5]. The minute amounts of compounds in polyacrylonitrile copolymers are rather difficult to identify by the spectroscopic method [5].

From Table 1 it is evident that by elemental analysis on a HewlettPackard model 115 analyzer, the sum of $\mathrm{C}, \mathrm{H}$ and $\mathrm{N}$ does not amount to $100 \%$, the difference being caused by oxygen, sulfur and chlorine contained in comonomers (modacrylic fibres) and by a flatting agent. Polyacrylonitrile fibre Dralon was found to contain $0.39 \%$ sulfur and about $0.3-0.5 \% \quad \mathrm{TiO}_{2}$ as flatting agent [ ${ }^{6}$.

The infrared spectra of pure polyacrylic fibres $(100 \%$ grade) have been investigated earlier by several authors, the works of Yamadera's group [ $\left.{ }^{7}\right]$ arousing special interest. His work has also been used as a basis in this investigation at the interpretation of absorption bands of spectra of modified polyacrylonitrile and modacrylic fibres.

The goal of this work is to elucidate to what extent infrared spectrometry can be used to characterize and identify modified polyacrylic and modacrylic fibres. This is rather complicated because trace amounts of tens of different compounds must be detected in acrylonitrile copolymers. The authors have also dealt with the identification of individual polyacrylic (modified) and modacrylic fibres produced under various trade names, using either the pyrolysis gas chromatographic $\left.{ }^{8}\right]$ or microscopic method for distinguishing fibres of different cross-sections [ ${ }^{9}$ ].

Table 2 presents the absorption bands of infrared spectra of pure polyacrylic, polyacrylic and modacrylic fibres of different origin. Data of Yamadera et al. (taken from [5]) about pure polyacrylonitrile have been used for interpretation, but similarly to the modified polyacrylonitrile fibres, a large number of monomers polymerized into the main polymer in low concentrations only, must be dealt with, and therefore spectral data were taken from the literature.

Chemical fibres of this type are characterized and identified on the 


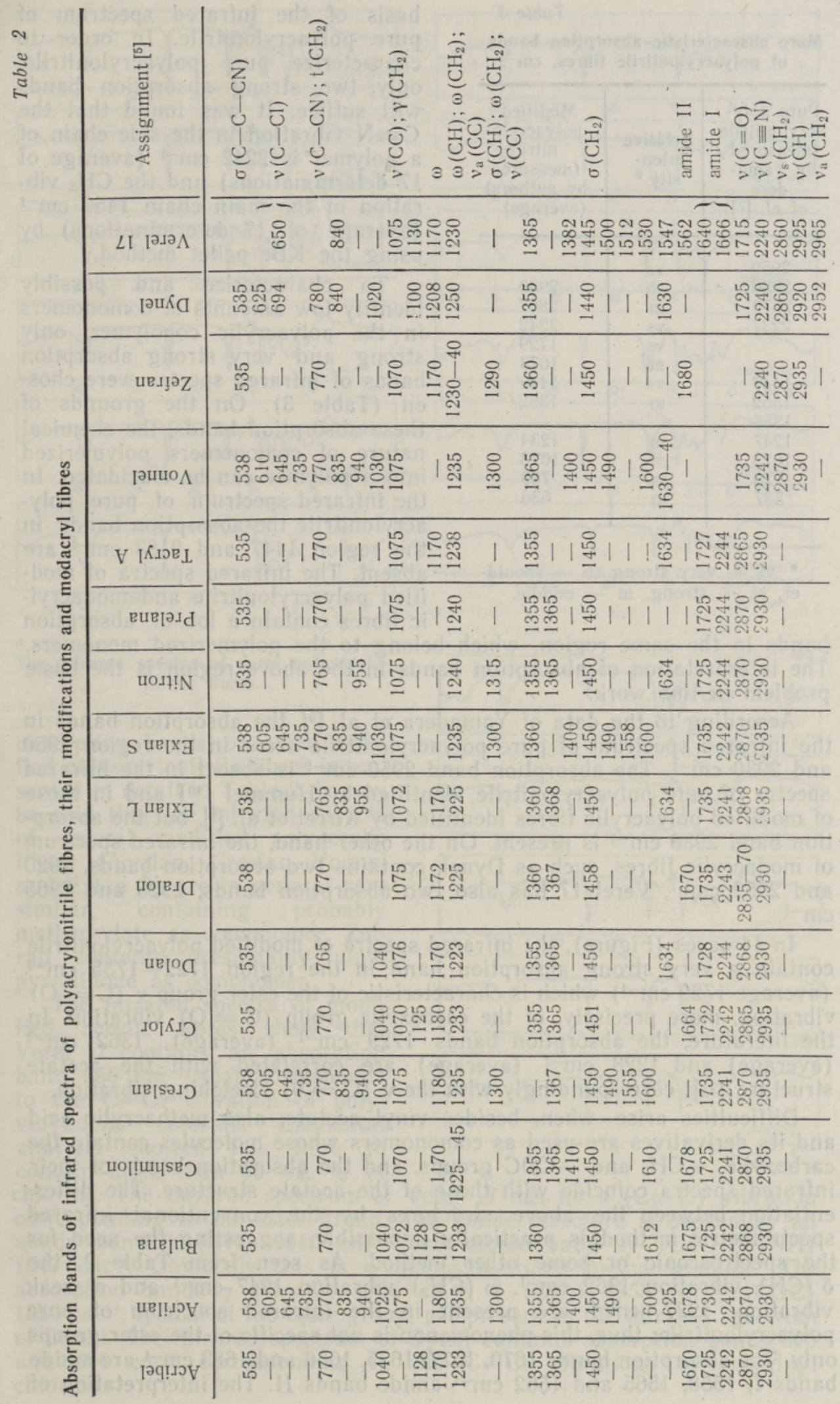


Table 3

More characteristic absorption bands of polyacrylonitrile fibres, $\mathrm{cm}^{-1}$

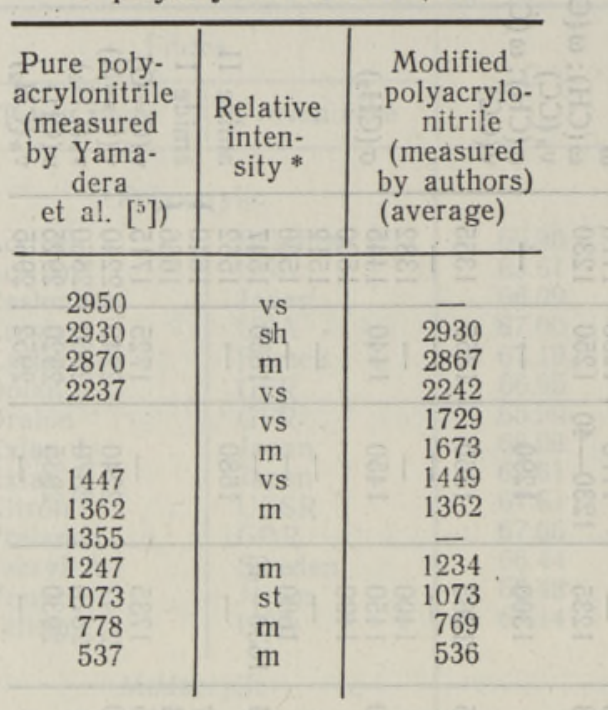

* vs - very strong sh - shoulder, st - strong, $\mathrm{m}$ - middle. basis of the infrared spectrum of pure polyacrylonitrile. In order to chanacterize pure polyacrylonitrile, only two strong absorption bands will suffice. It was found that the $\mathrm{C} \equiv \mathrm{N}$ vibration in the side chain of a polymer is $2242 \mathrm{~cm}^{-1}$ (average of 17 determinations) and the $\mathrm{CH}_{2}$ vibration of the main chain $1450 \mathrm{~cm}^{-1}$ (average of 17 determinations) by using the $\mathrm{KBr}$ pellet method.

To characterize and possibly identify low amounts of comonomers in the polyacrylic copolymer, only strong and very strong absorption bands of infrared spectra were chosen (Table 3). On the grounds of these absorption bands, the chemical nature of comonomers polymerized into a polymer can be elucidated. In the infrared spectrum of pure polyacrylonitrile the absorption bands in the region 1447 and $2183 \mathrm{~cm}^{-1}$ are absent. The infrared spectra of modified polyacrylonitrile and modacrylic fibres contain a lot of absorption

bands in the same region, which belong to the polymerized monomers. The interpretation of absorption bands in the above region is the basic problem in this work.

According to the data of Yamadera et al. [5], the absorption bands in the infrared spectrum of pure polyacrylonitrile occur in the region 2950 and $2930 \mathrm{~cm}^{-1}$. The absorption band $2950 \mathrm{~cm}^{-1}$ is absent in the infrared spectra of pure polyacrylonitrile identified by Hummel $\left.{ }^{[10}\right]$ and in those of modified polyacrylic fibres identified by Kirret et al. [ ${ }^{8}$, but the absorption band $2930 \mathrm{~cm}^{-1}$ is present. On the other hand, the infrared spectrum of modacrylic fibres, such as Dynel, contains two absorption bands, 2920 and $2952 \mathrm{~cm}^{-1}$, Verel 17 has also two absorption bands, 2925 and 2965 $\mathrm{cm}^{-1}$.

In 14 cases (Figure), the infrared spectra of modified polyacrylonitrile contain a very strong absorption band in the region $1722-1735 \mathrm{~cm}^{-1}$ (average $1729 \mathrm{~cm}^{-1}$ ) which is characteristic of the ester group $v(\mathrm{C}=\mathrm{O})$ vibration, more precisely, of the carboxylic group $(\mathrm{C}=\mathrm{O})$ vibration. In the literature, the absorption bands $1729 \mathrm{~cm}^{-1}$ (average), $1362 \mathrm{~cm}^{-1}$ (average) and $1228 \mathrm{~cm}^{-1}$ (average) are correlated with the acetate structure $\left[{ }^{11}\right]$, correspondingly with the $v(\mathrm{C}=0)$ stretching vibration.

Difficulties arise when, besides vinyl acetate, also methacrylic acid and its derivatives are used as comonomers whose molecules contain the carboxylic, $-\mathrm{CH}_{3}$ and $-\mathrm{COC}$ groups, and the absorption bands of their infrared spectra coincide with those of the acetate structure. The differentiation between the above structures by the conventional infrared spectrometric method is practically impossible, suggesting the need for the spectroscopic or some other method. As seen from Table 2, the $\delta(\mathrm{CH})$ vibration $1362 \mathrm{~cm}^{-1}$, $\omega\left(\mathrm{CH}_{2}\right)$ vibration $1247 \mathrm{~cm}^{-1}$ and a weak vibration $1227 \mathrm{~cm}^{-1}$ are present in the infrared spectrum of pure polyacrylonitrile; thus, this phenomenon is not specific of the ester groups only. The absorption bands $1670,1677,1675,1666$ and $1683 \mathrm{~cm}^{-1}$ are amide bands I, 1558,1565 and $1562 \mathrm{~cm}^{-1}$ amide bands II. The interpretation of 

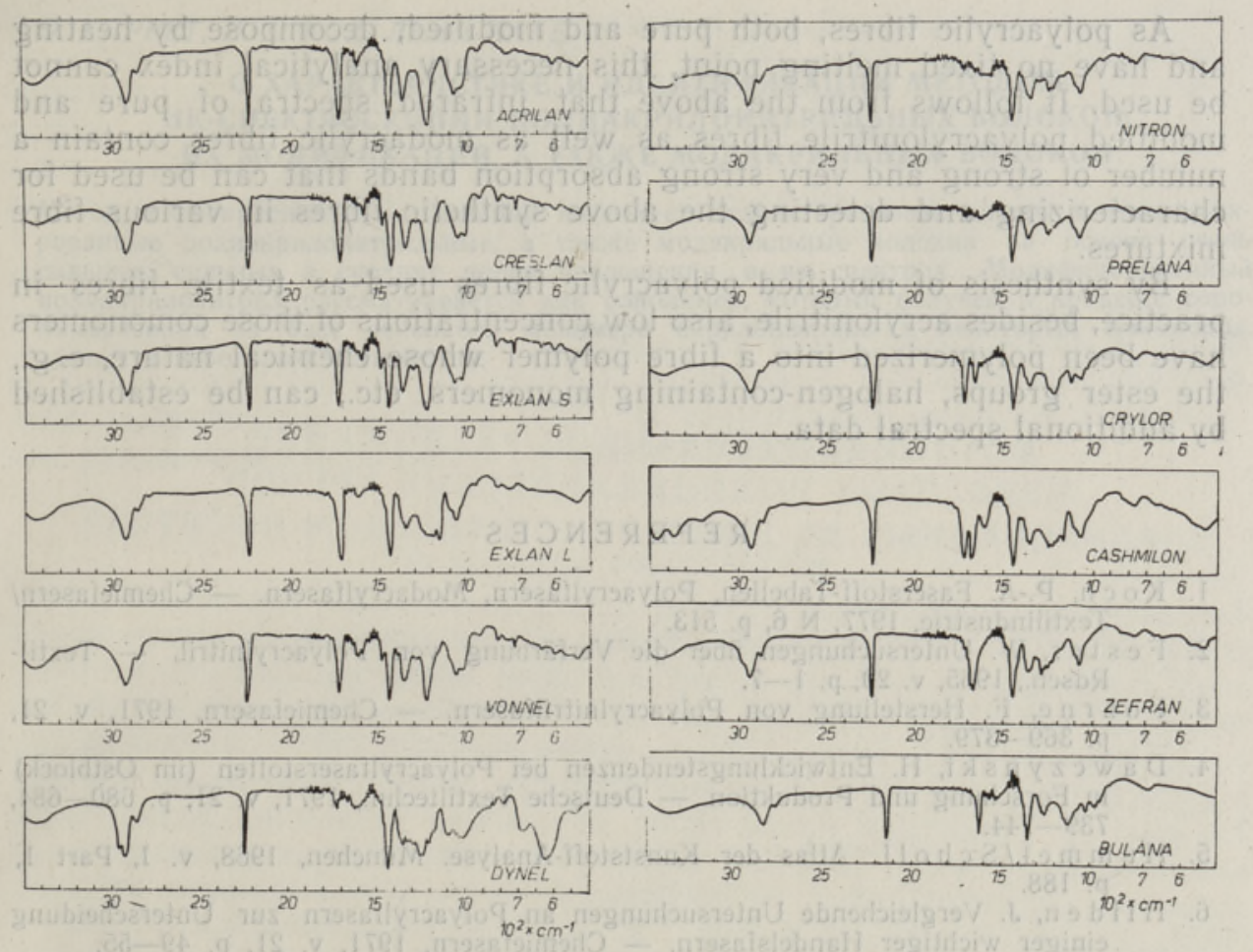

The infrared spectra of some polyacrylonitrile fibres.

absorption bands of other modified polyacrylonitrile fibres is presented in detail in Table 2. It may be said that the infrared spectra of several modified polyacrylic fibres (Acrilan, Creslan, Vionnel and Exlan S) are in general very similar, containing probably methacrylate as comonomer. Zefran contains presumably vinyl pyrrolidone as comonomer.

The infrared spectra of modified acrylic fibres show that Verel 17 contains an absorption band $650 \mathrm{~cm}^{-1}$ that corresponds to the $\mathrm{C}-\mathrm{Cl}$ vibration of polyvinylidene chloride. Elemental analysis showed this fibre to contain more than 30 wt. $\%$ of chlorine. The infrared spectrum of Verel 17 has no $v(\mathrm{C}=\mathrm{O})$ vibration corresponding to the ester group. The amide structure is proved by an amide band I (NH) $1640 \mathrm{~cm}^{-1}$ and amide band II $(\mathrm{C}-\mathrm{N})(\mathrm{NH})$ $1547 \mathrm{~cm}^{-1}$. Obviously this is a monosubstituted methacrylamide. The absorption bands $\gamma(\mathrm{C}=\mathrm{O}) 1725 \mathrm{~cm}^{-1}, \delta\left(\mathrm{CH}_{3}\right) 1355 \mathrm{~cm}^{-1}$, (COC) $1250 \mathrm{~cm}^{-1}$, typical of the ester group, are present in the infrared spectrum of Dynel. The infrared spectrum of Dynel contains absorption bands 625 and $694 \mathrm{~cm}^{-1}$ corresponding to the $\mathrm{C}-\mathrm{Cl}$ vibrations of polyvinyl chloride. 
As polyacrylic fibres, both pure and modified, decompose by heating and have no fixed melting point, this necessary analytical index cannot be used. It follows from the above that infrared spectra of pure and modified polyacrylonitrile fibres as well as modacrylic fibres contain a number of strong and very strong absorption bands that can be used for characterizing and detecting the above synthetic fibres in various fibre mixtures.

By synthesis of modified polyacrylic fibres used as textile fibres in practice, besides acrylonitrile, also low concentrations of those comonomers have been polymerized into a fibre polymer whose chemical nature, e. g., the ester groups, halogen-containing monomers, etc., can be established by additional spectral data.

\section{REFERENCES}

1. Koch, P.-A. Faserstoff-Tabellen, Polyacrylfasern, Modacrylfasern. - Chemiefasern/ Textilindustrie, 1977, N 6, p. 513.

2. Fester, W. Untersuchungen über die Verfärbung von Polyacrylnitril. - TextilRd'sch., 1965 , v. 20 , p. $1-7$.

3. Fourne, F. Herstellung von Polyacrylnitrilfasern. - Chemiefasern, 1971, v. 21, p. $369-379$.

4. D a w c z y n ski, H. Entwicklungstendenzen bei Polyacrylfaserstoffen (im Ostblock) in Forschung und Produktion. - Deutsche Textiltechn., 1971, v. 21, p. 680-684, $739-744$.

5. Hummel/Scholl. Atlas der Kunststoff-Analyse. München, 1968, v. I, Part 1, p. 188.

6. Hilden, J. Vergleichende Untersuchungen an Polyacrylfasern zur Unterscheidung einiger wichtiger Handelsfasern. - Chemiefasern, 1971, v. 21, p. 49-55.

7. Yamadera, R., Tadokoro, H., Murahashi, S. Normal vibrations of polyacrylonitrile and deuterated polyacrylonitriles. - J. Physics, 1964, v. 41, p. 1233.

8. Kirret, O., Kü 11 i k, E., Lü ü s, M. Polüakrüülnitriil ja multipolümerisaatkiudude identifitseerimine pürolüüsi-gaasikromatograafia meetodil. - ENSV TA Toim. Keemia, 1971, v. 20, N 2, p. $97-100$.

9. Ko ch, P.-A. Faserstoff-Tabellen, Polyacrylfasern, Modacrylfasern. - Chemiefasern/ Textilindustrie, $1977, \mathrm{~N} 6$, p. 513-524.

10. Hu m m e 1, D. O. Polymer Spectroscopy. Weinheim, 1974, p. 143.

11. Hummel/ $\mathrm{Schol1}$. Atlas der Kunststoff-Analyse. München, 1968, v. I, Part 1, p. 111.

Academy of Sciences of the Estonian SSR, Institute of Chemistry

Received

Feb. 2, 1982

O. KIRRET, P.A. KOCH, Lilja LAHE

\section{POLUAKROOLNITRIILKIUDUDE, NENDE MODIFIKATSIOONIDE JA MODAKRUOLKIUDUDE ISELOOMUSTAMINE NING IDENTIFITSEERIMINE INFRAPUNASE SPEKTROMEETRIA MEETODIL}

Puhaste ja modifitseeritud polüakrüülnitriilkiudude ning modakrüülkiudude iseloomustamiseks saab kasutada nende infrapunastes spektrites esinevaid väga tugevaid, tugevaid ja keskmise tugevusega absorptsiooniribasid.

Modifitseeritud polüakrüülnitriili tuleb vaadelda kui kopolümeeri, milles pōhimonomeeri akrüülnitriili kõrval on kopolümerisatsioonil kasutatud väiksemates kogustes ühte, kahte ja koguni kolme monomeeri; viimaste identifitseerimine on küllaltki komplitseeritud, kui kasutada ainuüksi infrapunast spektromeetriat. 
О. КИРРЕТ, П.-А. КОХ, Л ИЛЬЯ ЛАХЕ

О ХАРАКТЕРИСТИКЕ И ИДЕНТИФИКАЦИИ МЕТОДОМ ИК-СПЕКТРОСКОПИИ ПОЛИАКРИЛОНИТРИЛЬНЫХ ВОЛОКОН, ИХ МОДИФИКАЦИИ, А ТАКЖЕ МОДАКРИЛЬНЫХ ВОЛОКОН

Метод инфракрасной спектроскопии позволяет охарактеризовать чистые и модифицированные полиакрилонитрильные, а также модакрильные волокна на основе очень сильных, сильных и средних полос поглощения в их спектрах. Модифицированный полиакрилонитрил рассматривается как сополимер, который получен в процессе сополимеризации на базе основного мономера акрилонитрнла и некоторых мономеров, взятых в небольшом количестве. 